\title{
Small Business Development in Nizhilinsky Nasleg Area of the Kobyaysky Municipal District
}

\author{
Anna V. Mikhaylova \\ Maxim Ammosov North East Federal State University, Russian Federation \\ Corresponding Email: mikanya23@mail.ru
}

\section{Doi:10.5901/mjss.2015.v6n6s7p223}

\section{Abstract}

Among the numerous factors of social and economic development of the region is the development of small business located in rural areas engaged in agrarian sector as well as development of inter-firm cooperation, the agricultural cooperatives. Article is devoted to the analysis of legal issues related to the development of SMEs, development of practical recommendations for development of municipalities in the form of rural settlements using a case study of the Nizhilinsky Nasleg area of the Kobyaysky municipal district. Using the example of consumer cooperative 'Kytalyktakh' the paper analyses the development features of agricultural cooperatives in rural area of the Republic of Sakha (Yakutia).

Keywords: SME, regional development, regional policy, rural settlements, regional economy

\section{Introduction}

Small business is a vital component of developed economies. It has to carry out a number of functions, which enable the economy to develop harmoniously. The influence of SMEs covers all countries of the world, subjects of the Russian Federation, including an active expansion in the territory of the Republic of Sakha (Yakutia). Proceeding from it, an important element is development of business and small business in particular is the relevance of the real research is that conditions the innovative economy. During 2014, growth rates of economy of the Republic of Sakha (Yakutia) steadily exceeded the national average indicators. Despite the difficult foreign policy and external economic situation that developed in the second half of the year 2014, the main macroeconomic indicators of the Republic of Sakha (Yakutia) received positive growth rate: a gross regional product $-102.5 \%$, industrial production $-104.4 \%$, investments into fixed capital $-102.4 \%$, the volume of construction works $-105.3 \%$, a turn of retail trade $-10.5 \%$, the real located monetary income of the population - 100.1\% (Government resolution, 2015). However, gaining a positive impact on development of economy and strengthening of production competitiveness on behalf of the SMEs require the development of such small forms of business that would consider the characteristics of the territory.

The review of literature provides justification for the need and expediency of SME development as complicated entities featuring the variety of management models of economic development, forms of ownership, a variety of financial interests of economic the entities and investors, generally followed by a reduction of the state support (Volkova-Rarog, 2004; Bimbad, 2011; Konoplev, 2009). The policy of the state has to be directed on increase of efficiency of institutional and land transformations, formation of a layer of real owners, uniform understanding of the mechanism of stimulation of business activity. It has to be oriented at the development of different forms of agrarian cooperation and integration, protection of economic entities against unfair competition. In this situation the important supporting and developing factor for subjects of SMEs is the credit market with the valid possibility of receiving much-needed credit resources.

\section{Research Framework}

Research objective is the complex analysis of problems in development of small rural businesses, and development of practical recommendations on development of SMEs in in Nizhilinsky Nasleg area of the Kobyaysky municipal district, providing increase of their economic and social efficiency. An object of research is the developed system of SMEs taking into account regional features. The municipality Nizhilinsky Nasleg has the status of the rural settlement (The law of the Republic of Sakha (Yakutia), 2008) from 30.11.2004 173-Z No. 353-III 'About establishment of borders and about investment with the status of city and rural settlements of municipalities of the Republic of Sakha (Yakutia)'. An administrative center of the rural settlement is the village of Chagda. The most widespread form of small business in the 
village of Chagda are the country farms, which in recent years gain more and more effective development, provided with rural credit cooperation. Subject of the research are set of the economic relations arising in the course of functioning and development of SMEs engaged in the Development of consumer cooperative 'Kytalyktakh' in the territory of the rural settlement of Kobyaysky municipal district.

Methodological basis of research is set on theoretical development within the management theory as well as the legal documents, regulations, program documents of the Russian Federation and the Republic of Sakha (Yakutia) in the sphere of small business. The method of research used is the comparative analysis, the analysis of documents, statistical analysis.

\section{Results}

\subsection{Standard and legal regulation in the sphere of small business}

The system of legal regulation of activity of subjects of SMEs consists of legal acts of various validity and level of acceptance. The considered perspective is repeatedly discussed in scientific literature. Konoplev (2009, pp. 10-1) proved situation that "standard and legal regulation of small business represents the hierarchical system of acts consisting of seven elements: international contracts of the Russian Federation, conventional principles and norms of international law; Constitution of the Russian Federation 1993; Codes and other federal laws: The civil code of the Russian Federation, the Labor code of the Russian Federation, the Federal law of 24.07.2007 No. 209-FZ 'About development of SMEs in the Russian Federation'; regulations of the Russian President, the Government of the Russian Federation and regulations of the ministries and departments of the Russian Federation; regulations of territorial subjects of the Russian Federation; corporate regulations; - customs of a business conduct".

Legislative regulation of activity of subjects of SMEs is carried out by the Federal law of July 24, 2007 No. 209-FZ 'About development of SMEs in the Russian Federation'. This Law, governing the relations in the sphere of development of SMEs, defines categories of subjects of SMEs and infrastructure of their support, types and forms of such support. In addition, provisions of the Law on SMEs establish features of standard legal regulation of activity of subjects of small and medium business. However, in our opinion, the specified Law does not define that it is necessary to understand as the term 'development of small and medium business' in relation to regulation of the specified subjects.

The contents of the tax law allow to draw a conclusion that in relation to subjects of small business first of all it is necessary to speak about such special tax modes as the simplified system of the taxation and system of the taxation in the form of a uniform tax on imputed income. As Smagina (2009) specifies, "directly persons conducting small or medium business note that at a choice of a kind of activity, and also creation of the enterprise they were attracted by the special tax modes provided for the economic entities. In particular, such modes as the simplified system of the taxation and system of the taxation in the form of a uniform tax on imputed income" are the most actual (Smagina, 2009, p. 18).

The state policy of the Republic of Sakha (Yakutia) in the field of development of SMEs is part of social and economic policy of the Republic of Sakha (Yakutia) and represents a set of the legal, political, economic, social, informational, consulting, educational, organizational and other measures that are carried out by public authorities of the Republic of Sakha (Yakutia) and aimed is providing realization more whole also than the principles established by the Federal law 'About development of SMEs in the Russian Federation'. In the territory of the Republic of Sakha (Yakutia) works the system of the state and public institutes of support and development of subjects of SMEs. In pursuance of legislative and subordinate regulations are approved and regional target programs of support of SMEs, which are also regulations work. Programs of development of subjects of SMEs are accepted and at the municipal level of subjects of the Russian Federation. An example is the State program of the Republic of Sakha (Yakutia) 'Development of business in the Republic of Sakha (Yakutia) for 2012-2017', the President of RS(Ya) approved by the Decree of 12.10.2011 N 980 'About a state program of the Republic of Sakha (Yakutia) 'Development of business in the Republic of Sakha (Yakutia) for 2012 - 2017'. The specified program is accepted for implementation of the Federal law of July 24, 2007 N 209-FZ "About development of SMEs in the Russian Federation', the Law of the Republic of Sakha (Yakutia) of December 29 2008 645-Z N 179-IV 'About development of SMEs in the Republic of Sakha (Yakutia)'. It is also necessary to note the program of social and economic development of 'Nizhilinsky Nasleg' municipality for 2012-2016 accepted by the Decision of naslezhny Council of deputies of municipality 'Nizhilinsky Nasleg' of November 12, 2012 No. 14. Thus, today in the Russian Federation has a complete system of standard legal regulation for SMEs. This system includes regulations of federal, regional and municipal levels.

We shall agree with the situation described by Volkova-Rarog $(2004$, p. 9) that "the institute of small business represents a complex legal institute of branch of the enterprise right combining the public and private-law relations 
regulated by norms of enterprise, civil, financial and administrative law with application of imperative and dispositive methods of influence". Considering realities of today, we believe possible distribution of this conclusion to legal institute of SMEs with extension of the list of branches of the legislation by inclusion of standards of the labor law in it. Thus, the institute of SMEs represents the complex legal institute of branch of the enterprise right combining the public and privatelaw relations regulated by standards of the enterprise, civil, financial, administrative, labor law with application of imperative and dispositive methods of influence.

It is necessary to address to clearing of essence of the considered phenomenon also. First, law-making and the operating system of the right are, in our opinion, as object of law-making policy in the sphere of development of business and at the same time act as the main means, the instrument of its realization by means of which subjects of such policy make the impact on the enterprise relations. Secondly, this kind of law-making policy includes in object of the attention not only the enterprise relations, but also the socio-political relations, activity of numerous subjects of its formation and realization - from government bodies of the power, title law-making structures having rights of a legislative initiative to local governments, collective educations, and certain citizens. Thirdly, distinctive feature of law-making policy in the sphere of business consists that it is a form of activity of subjects of the enterprise relations directed on improvement of the current legislation by expression of public opinion as one of effective forms of law-making policy. Such policy on the nature, on the one hand, is directed on improvement of legal means, and with another - assumes use of political and legal tools for ensuring progressive development of the enterprise relations.

Thus, the field for standard and legal regulation in the sphere of business activity remains rather wide. Measures for active financial, tax and bank support of domestic businessmen, considerable reduction of rates of bank percent for the granted loans, especially in the sphere of high technologies, agriculture and production branches have to become priorities of law-making policy here, in our opinion.

Addressing to agro-industrial complex it should be noted that rendering the state support to agriculture is not only and not so much the Russian phenomenon. In our opinion, the state support to agricultural producers has to be carried out in the following main directions: formation and functioning of the market of agricultural production, raw materials and food; financing, crediting, insurance, preferential taxation of the agrosphere; protection of interests of domestic producers at implementation of foreign economic activity; development of science and implementation of scientific activity in the sphere of agroproduction; development of the social sphere of the village; other directions determined by the legislation of the Russian Federation. Credit and financial support of agriculture is very important. For the guaranteed solution of such major problems in the long term of effort and attention will be concentrated on support of new strategically important directions - development of infrastructure, logistics and processing.

\subsection{Features of development of small business in the territory of the rural settlement Nizhilinsky Nasleg municipality}

The territory of Nizhilinsky Nasleg municipality occupies 283,500 hectares. Nasleg - is a small rural area. The territory of a region borders from North side to Aryttakhsky and Tyayinsky by naslega, from South side to Kobyaysky naslegy, from East side the Mountain ulus, from West side the Vilyuysky ulus, Lyuchcheginsky the second and Aryttakhsky naslega. The population of the Nizhilinsky nasleg as of 01.01 .2015 is 544 persons, among them men -122 , women -122 , children from 0 to 6 years - 58 people, from 7 to 16 years - 114 people, the number of able-bodied population at workingage -290 people. The main form of business in the territory of a nasleg is agricultural activity. There is a consumer cooperative 'Kytalyktakh', nine country farms, and 80 units of personal subsidiary farm. Besides, in a naslega there are six power-saw benches which work satisfies needs of the population for timberwork.

All above farms of a nasleg are engaged in such types of agriculture as: meat and dairy cattle breeding, meat horse breeding, poultry farming, hunting and fish trade, cultivation of potatoes and vegetables, preparation of a rough forage, preparation of the wood for construction and timber. Development of farming as forms of small business in agriculture, demands to itself advanced organizational and economic, administrative and legal approaches that causes special relevance and the importance of a subject of the real research.

In the sphere of a private property in the village the following organizational and legal forms of agricultural production differ now: - agricultural production cooperatives, including and their main version - collective farms; consumer agricultural cooperatives; - the collective enterprises (the former state farms); - societies with limited or additional liability; - opened and closed joint stock companies; - full and limited partnerships (general partnership); associations of country (farmer) farms and agricultural cooperatives; - subsidiary agriculture of the state enterprises; country (farmer) farms; - personal subsidiary farms of citizens. The listed subjects of the agrarian entities are indispensable participants of the agrarian legal cooperation developed in agricultural production in municipality Nizhilinsky Nasleg. 


\subsection{Development of consumer cooperative Kytalyktakh}

One of the rural credit cooperatives operating in the territory of the Republic of Sakha (Yakutia) is the agricultural consumer credit cooperative Kytalyktakh in the village of Chagda, Nizhilinsky of a nasleg founded in 2009. Activity of cooperative is directed on increase of a standard of living of the population by access to financial resources, creations of conditions for small business, and creation of new workplaces. Since 2011, the cooperative started using in the work information system on crediting of agricultural producers with assistance of the Ministry of Agriculture of the Republic of Sakha (Yakutia). The system allows creating quickly and easily a package of documents (for borrowers) on loans of members of cooperative which includes: application for a loan, questionnaire of the borrower, loan agreement, contract of guarantee, contract of pledge. Experience of agricultural consumer credit cooperative Kytalyktakh is applied in other agricultural credit cooperatives of the republic. Creation of credit cooperatives in the village enables to strengthen a financial position of small producers in production and development of small agrobusiness; to provide villagers with necessary credit resources and financial services; to lower unemployment rate by granting additional workplaces; to expand a range of the provided financial services in the village; to raise a standard of living of country people; to increase the level of economic education of the population in rural areas.

Problems of development of SMEs in the republic, including in the territory of Nizhilinsky Nasleg municipality are caused by a variety of reasons, first of all, the expressed disproportions in a level of development of municipalities of the region. Feature of spatial structure of placement of demographic and production capacity of the republic is its concentration in the Western, Southern and Central areas of the republic. Therefore, considerable differentiation of volume of paid household services to the population in Nizhilinsky Nasleg municipality caused by concentration of a services sector in the regional center.

\section{Conclusion}

Proceeding from stated it is represented that the system of credit cooperation in the village will allow to strengthen a financial position of small producers in agro-industrial production and development of small agrobusiness; to provide villagers with necessary credit resources and financial services; to lower unemployment rate by granting additional workplaces; to expand a range of the provided financial services in the village; to raise a standard of living of country people; to increase the level of economic education of the population in rural areas.

In this regard in the territory of Nizhilinsky Nasleg municipality requires the creation and provision of favorable conditions for development and increase of competitiveness of small business. It in turn this means the following: 1. Creation of motivation and additional incentive for involvement of the unoccupied population in the sphere of small business; 2. Ensuring access of subjects of small business of a nasleg to the financial, property support given within the state support of SMEs; 3 . Creation of necessary conditions for development of agricultural producers.

Now for successful development of small business in the territory of the Republic of Sakha (Yakutia), in general, is created the institutional base, which is urged to create the corresponding conditions for its functioning according to specifics of business activity. However, the number of small enterprises in the territory of a nasleg and in general in the republic does not increase, and is even reduced. There is no need to detail the reasons for which there is a reduction, it should be noted only that in many respects it depends on the taxes established for businessmen.

Proceeding from specified, formation and creation of the favorable tax environment for small business, including simplification of procedure of conducting business activity is obviously necessary. Besides, the package of measures, directed on increase and stimulation of development of business in the sphere of agriculture is necessary for effective development of small business in a naslega. It is necessary to stimulate development of family livestock farms on the basis of country farms. Agriculture, in particular the beginning farmers, are in great need in the state support.

Successful development of agricultural consumer credit cooperation in the village requires carrying out the following actions: preparation and professional development of specialists of rural credit cooperatives, by the organization of constantly operating system of preparation and professional development, holding the training seminars according to special plans and work exchange of experience seminars; state support of creation and work of agricultural cooperatives. Thus, change in forms and methods of state regulation of SMEs, including the reform of tax system will promote growth of subjects of small business, creation of new workplaces in a nasleg, and in general - the economic development of the Republic of Sakha (Yakutia). We believe the developed recommendations will become a basis for further social and economic development of municipality, the Republic of Sakha (Yakutia) and the region in general. 


\section{References}

Bimbad, A.Ya. (2011.) The state and property support of subjects of small business at the present stage. Moscow.

Government resolution (2015), The resolution of the government of the Republic of Sakha (Yakutia) of March 14, 2015 \#. 53 "About results of social and economic development of the Republic of Sakha (Yakutia) for 2014 and the main objectives for 2015" Retrieved from September 012015 - Union of Right Forces "ConsultantPlus";

Konoplev, S. A. (2009). Legal regime of subjects of small business. Moscow.

Smagina, I.A. (2009). Taxes of subjects of small business. Right and economy. 11, 15-27.

The decision of small region Council of deputies of municipality "Nizhilinsky Nasleg" of November 12, 2012 No. 14;

The Federal law $(1995,2011)$ of 08.12.1995 N 193-FZ (an edition of 03.12.2011) "About agricultural cooperation" Retrieved from September 102015 //Union of Right Forces "ConsultantPlus";

The law of the Republic of Sakha (Yakutia) (2008) of December 292008 645-Z N 179-IV "About development of SMEs in the Republic of Sakha (Yakutia)" Retrieved from September 01 2015. Union of Right Forces "ConsultantPlus";

The order of the Government of RS(Ya) of 03.04.2006 N 382-p "About support of credit cooperation in the village within implementation of the national priority project "Development of Agrarian and Industrial Complex" in the Republic of Sakha (Yakutia) in the "Stimulation of Small Forms of Managing" direction for 2006" (together with "The provision on an order of financing of actions for support of cooperation within implementation of the national priority project "Development of Agrarian and Industrial Complex" in the "Stimulation of Small Forms of Managing" direction for 2006") Retrieved from September 10 2015. Union of Right Forces "ConsultantPlus";

The resolution of the Government of the Russian Federation of July 14, 2012 No. 717 "About a state program of development of agriculture and regulation of the markets of agricultural production, raw materials and food for 2013-2020" Retrieved from September 01 2015. Union of Right Forces "Guarantor";

Volkova-Rarog, Yu.A. (2004). Small business (legal aspect). Moscow. 